\title{
Water Hyacinth (Eichhornia crassipes) Biology and Its Impacts on Ecosystem, Biodiversity, Economy and Human Well-being
}

\author{
Abera Hailu Degaga \\ Department of Wildlife \& Ecotourism Management, Wolkite University, P.O. Box 07, Wolkite, Ethiopia
}

\begin{abstract}
The aim of this review was to show water hyacinth biology, chemical composition and its negative impacts on aquatic ecosystem, biodiversity, economy and human wellbeing. Water hyacinth is challenging the ecological stability of freshwater bodies. It is native to the Amazon Basin in Brazil and other nearby South American countries. In Africa, the first introduction of water hyacinth was in Egypt in 1880. In Ethiopia, water hyacinth was officially reported in 1956 in Koka Lake and the Awash River. Nutrients and temperature are considered the strongest determinants for water hyacinth growth and reproduction. Under favorable conditions, water hyacinths can double its mass every 5 days and it also grows from seed, which can remain viable for 20 years. Due to its extremely fast growth, the weed has become the major floating water weed of tropical and subtropical regions. In the absence of natural enemies, the weed quickly becomes invasive, colonizing slow moving waters resulting in thick and extensive mats which degrade aquatic ecosystems and limit their utilization. These mats affect fisheries and related commercial activities, functioning of irrigation canals, navigation, hydroelectric programmes and tourism. Its $95 \%$ mass weight is water from $5 \%$ dry matter $50 \%$ is silica and $30 \%$ is $\mathrm{K}, 15 \% \mathrm{~N}$ and $5 \%$ protein. The spread of this invasive plant is difficult to manage and not easy to reverse. Its impact is not only loss of biodiversity in aquatic ecosystems but also economic development and human wellbeing. It supports as breeding ground for vectors and pests. Hand removal is most effective for small infestations while mechanical harvesting can be an effective tool for removing larger infestations. The best method to control water hyacinth is to prevent it from entering a water body. This can be through education programs that have proved to be an effective tool in preventing further spread into catchments by people for ornamental purposes. So Ethiopian Government has to declare water hyacinth and other invasive species as a national pest and then put legislation in place to control them.
\end{abstract}

Keywords: aquatic ecosystem, aquatic weed, invasive plant species, fast growth, mat formation

DOI: $10.7176 / \mathrm{JNSR} / 9-12-04$

Publication date: June $30^{\text {th }} 2019$

\section{Introduction}

The spread of invasive species is difficult to manage and not easy to reverse, this threatens not only biodiversity of aquatic ecosystems but also economic development and human wellbeing (UNEP, 2012). Water hyacinth (Eichhornia crassipes) is an invasive aquatic plant associated with a variety of ecological and economic effects on freshwater ecosystems (Center, 1994). It is a free-floating aquatic plant that grows in ponds or slow moving waterways. It is a perennial monocotyledonous crop that belongs to the Pontederiaceae family. It is native to the Amazon Basin in Brazil and other nearby South American countries (Chunkao, et al., 2012). And Holm, et al. (1997) reported that, E. crassipes, a native of South America, is a major freshwater weed in most of the frost-free regions of the world and is generally regarded as the most troublesome aquatic plant. It is considered the worst aquatic weed in the world (FAO, 2002). In Africa, the first introduction of water hyacinth was in Egypt in 1880 (Warnimont, 1965); the main aquatic weed in East Africa is Water hyacinth (FAO, 2002). In Ethiopia, water hyacinth was officially reported in 1965 in Koka Lake and the Awash River (Wondie, 2013; Firehun, et al., 2014) and infestation of Lake Tana was officially recognized in 2011 (Ayalew, et al., 2012). It has been recognized as the most damaging aquatic weed in Ethiopia since 1965 (Wondie, 2013). In Lake Tana in addition to water hyacinth, other two floating invasive weeds: Azolla and Water Lettuce, were reported (Wassie, et al., 2014).

Water hyacinth reproduces both sexually and asexually. The rapid increase and spread of the plant into new areas is due particularly to its vegetative reproduction, a single plant being able to develop very rapidly a significant infestation (Rakotoarisoa, et al., 2015). Water hyacinth has a rapid propagation and morphological characteristics that makes the weed well adapted to rapid distance dispersal and successful colonization of varying habitats in a short time (Obeid, 1984). Moving easily with water currents, winds or other accidental means, such as fishing nets and boats, the plant invaded rivers, canals, ponds, lakes, dams and other freshwater bodies. In the absence of natural enemies, the weed quickly becomes invasive, colonizing slow moving waters resulting in thick and extensive mats (Edward \& Musil, 1975) which degrade aquatic ecosystems and limit their utilization (Hill \& Cotzee, 2008). The negative impacts of water hyacinth are due to its dense, impenetrable mats which restrict access to water. These mats affect fisheries and related commercial activities, functioning of irrigation canals, navigation/transport, hydroelectric programmes and tourism (Navarro \& Phiri, 2000).

Nutrients and temperature are considered the strongest determinants for water hyacinth growth and reproduction (Wilson, et al., 2007). Salinity constraints generally limit water hyacinth establishment in coastal 
areas and within estuaries (Mangas-Ramirez \& Elias-Gutierrez, 2004). Due to its extremely fast growth, the weed has become the major floating water weed of tropical and subtropical regions. There for the aim of this review was to show water hyacinth biology, chemical composition and its negative impacts on aquatic ecosystem biodiversity, economy and human wellbeing. And to show water hyacinth is challenging the ecological stability of freshwater ecosystems.

\section{Biology, Chemical Composition and Ecology of Water Hyacinth}

The E. crassipes growth is extremely rapid and forms large populations of inter-connected shoots which is impenetrable mat. It forms dense, interlocking mats due to its rapid reproductive rate and complex root structure (Mitchell, 1985). The flowers are bluish purple, large and self-fertile. The seeds are produced in large numbers and are contained in capsules, each capsule containing up to 300 seeds (Manson \& Manson, 1958). The seeds can remain viable for 5-20 years (Matthews, et al., 1977). The plant can also reproduce vegetative through the production of horizontal stolons. Rakotoarisoa, et al. (2015) described that due to its high reproduction rate, the complex root structure and the formation of dense mats with up to two million plants per hectare can be found. Under favorable conditions, water hyacinth can double its mass every 5 days and it also grows from seed, which can remain viable for 20 years or longer (Patel, 2012; Frezina, 2013). The biotic seeds dispersals are birds thought to be transported over long distances (e.g. waterfowl and shore birds) and if coated in mud they may cling to both mammals and birds (Holm, et al., 1969; Batcher, 2000). While, wind is the abiotic dispersal, it will readily move the plant and the upright leaves in lakes and canals. Along rivers, water flow is the prime mover of vegetative material but strong winds may sometimes blow the plant upstream.

Water hyacinth draws all its nutrients directly from water. It absorbs heavy metals (Tiwari, et al., 2007), organic contaminants (Zimmels, et al., 2007), and nutrients from the water column (Aoi \& Hayashi, 1996). It comprises $95 \%$ water and 5\% dry matter of which $50 \%$ is silica, $30 \%$ Potassium, $15 \%$ Nitrogen and $5 \%$ protein (Makhanu, 1997). While Roger and Davis (1972) reported that the uptake of nitrogen by water hyacinth is 5 to 10 times as rapidly as phosphorous. It has been known to thrive well in nutrient-enriched fresh waters in tropical climatic zones. For this purpose it has been used in wastewater treatment facilities (Osumo, 2001).

The structure of a macrophyte assemblage plays a large role in determining composition of phytoplankton, zooplankton, fish, and birds in freshwater ecosystems (Meerhoff, et al., 2006). A shift in the primary-production base of a lake can resonate throughout the ecosystem, affecting multiple trophic levels both directly through changes in habitat availability and indirectly through shifts in energy pathways. Free floating plants are able to monopolize light and absorb nutrients from the water column, preventing phytoplankton and submersed vegetation from obtaining sufficient resources for photosynthesis (McVea \& Boyd, 1975). Altering ecosystem services and processes, reducing native species abundance and richness, and decreasing genetic diversity of ecosystems (Rands, et al., 2010) and also water hyacinth affects diversity, distribution and abundance of life in aquatic environments (Dereje, et al., 2017).

\section{Water Hyacinth Impacts on Biodiversity Loss}

Water hyacinth is challenging the ecological stability of freshwater bodies (Gichuki, et al., 2012), out-competing all other species growing in the vicinity, posing a threat to aquatic biodiversity (Patel, 2012). Besides suppressing the growth of native plants and negatively affecting microbes, water hyacinth prevents the growth and abundance of phytoplankton under large mats, ultimately affecting fisheries (Villamagna \& Murphy, 2010). This is because fish feed on phytoplankton. According to the Millennium Ecosystem Assessment (2005), freshwater ecosystems are among the most significantly human-altered systems in the world. While invasive species are considered the leading threat to global aquatic biodiversity (Mack, et al., 2000).

Most water hyacinth effects are lower phytoplankton productivity and dissolved oxygen concentrations beneath mats (Mironga, et al., 2011; Rommens, et al., 2003). Reduced phytoplankton productivity can decrease zooplankton abundance by decreasing food availability (Richards, et al., 1985; Maceina, et al., 1992). It also affects diversity, distribution and abundance of life in aquatic environments and enhances evapo-transpiration, thus affecting all aquatic organisms. The death and decay of water hyacinth vegetation in large masses create anaerobic conditions and production of lethal gases (Dereje, et al., 2017). Coverage of water hyacinth causes deoxygenation of water, and at times anoxia below the dense mats (Gerry, et al., 1997). Water quality effects include higher sedimentation rates within the plant's complex root structure and higher evapo-transpiration rates from water hyacinth leaves when compared to evaporation rates from open water (Gopal, 1987). A shift in the primaryproduction base of a lake can resonate throughout the ecosystem, affecting multiple trophic levels both directly through changes in habitat availability and indirectly through shifts in energy pathways (Amy, 2009). Dissolved oxygen less than $5 \mathrm{mg}$ per litter are known to adversely affect function and survival of most fishes and less than 2 mg per litter can lead to fish kills (Chapman, 1996). This low level of dissolved oxygen along the water column will happen when large water hyacinth mats prevent light infiltration or when a relatively large area of plants decompose at the same time. 
In the 1950s, within three years of its first sighting, it had spread $1600 \mathrm{~km}$ along the Congo River (Holm, et al., 1969); in Lake Tana in 2012 after a year of infestation officially recognized its estimation coverage was 20,000 hectares (BoEPLAU, 2012). This shows that if once introduced to favorable habitats, especially open waters, $E$. crassipes may spread very rapidly and can form dense monotypic mats. Which is impenetrable and blocking access both for transportation and aquatic living organisms in addition to adding to much organic matter to water bodies leading anoxia condition. The introduction and spread of non-native species contribute to the loss of aquatic species (Suski \& Cooke 2007).

\section{Economic Impacts of Water Hyacinth}

Because of its rapid growth and mat formation, E. crassipes has a range of detrimental effects on the economy sector. The dense mats disrupt socioeconomic and subsistence activities for example ship and boat navigation, restricted access to water for recreation, fisheries, and tourism (Ndimele et al., 2011; Patel, 2012). It physically interferes with water transport, communication and access. Infestations are increasing in Ethiopia, creating a range of problems including restricted access (Aweke, 1994). In Nigeria, Alimi \& Akinyemiju (1991) showed that costs of fuel and repairs to boats on infested waterways was approximately three times that on un-infested waterways. Economic losses also result from interference with recreational uses of water bodies (Gopal, 1987; Aweke, 1994). Heavy infestations by Water Hyacinth make fishing very difficult, or impossible (FAO, 2002). Fishermen are being troubled by a reduced range of fish species, loss of nets and impeded access (Terry, 1996). Water hyacinth was perceived to affect fisheries through reduced levels of production, a reduction in species diversity, poor quality fish, rising cost of operation resulting in lower income to fishers and higher prices to consumers (LVEMP, 1995). In Lake Victoria mats blocked breeding, nursery, and feeding grounds for economically important fish species, such as tilapia and Nile perch. Because water hyacinth mats can reduce natural predation and fisheries catchability, leading to increased abundance of certain species (Kateregga \& Sterner, 2009); but mats can also exclude certain species from important breeding, nursery, and feeding grounds (Twongo \& Howard, 1998). Expensive barriers or mechanical damage to hydro-electric installations and other structures such as bridges; for example, to the Owen Falls Dam on Lake Victoria (Hill, et al., 1999), there are also similar concerns in South Africa (Harley, et al., 1996), and Ethiopia (Aweke, 1994).

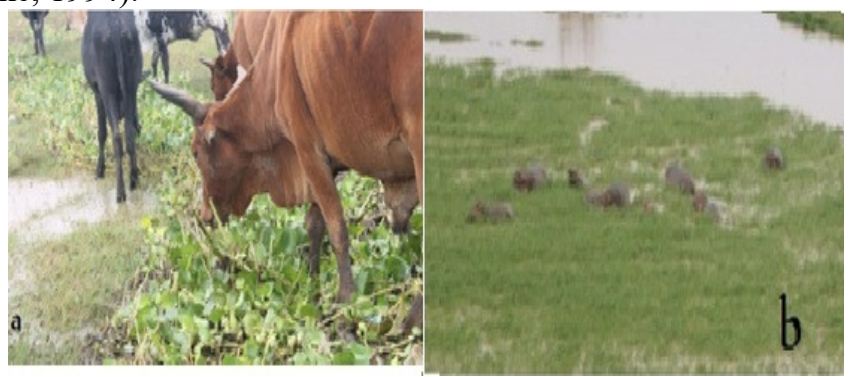

Figure 1: Shore of Lake Tana (a) Cattle grazing and water hyacinth (b) Hippopotamus select grass but do not graze water hyacinth (Source: Wassie, et al., 2014)

Water hyacinth has limited beneficial uses. Local communities around Lake Tana, they are worried about the invasion of their shore farm and grazing lands and cattle grazing the water hyacinth when there is no grass (Wassie, et al., 2014). It cannot be used as a livestock feed because it contains too much silica, calcium oxalate, potassium and too little protein (Osumo, 2001). Therefore, this leads reducing grazing potential, have a negative impacts on animal health, milk and meat quality (figure1) and economical reduction on the livestock sector of the country. Dereje, et al. (2017) mentioned that expansion of water hyacinth around Lake Tana and its competition with the native species the submerging grasses and other native species becomes devastated. These affect a lot of cattle which are directly and indirectly dependent on the grass. And also shore area floras which would be important for fish breeding grounds and livestock forage source in the vicinity become damaged.

\section{Water Hyacinth Impacts on Human Wellbeing}

E. crassipes may reduce water quality in various ways and encourage mosquitoes, snails and other organisms associated with human illnesses, including malaria, schistosomiasis, encephalitis, filariasis and cholera (Gopal, 1987; Harley, et al., 1996). It also increased health hazards i.e. incidence of malaria and schistosomiasis (Navarro \& Phiri, 2000). FAO (2002) also described that, this weed represents an environmental problem as well and indirectly a public health problem, since it may create a microhabitat suitable for the breeding of many vectors of human diseases and for hosting poisonous snakes. The infestation of water hyacinths (Eichhornia crassipes) in African lakes has increased breeding site availability for malaria vector species, An. funestus complex were reported from a water hyacinth mat (Minakawa, et al., 2002). Malaria vectors are able to breed amongst water hyacinth mats in Lake Victoria (Noboru. et al., 2012). 


\section{Water Hyacinth Control Methods}

Water hyacinth is extremely difficult to eradicate once established, the goal of most management

efforts is to minimize economic costs and ecological change (Amy, 2009). The optimum control method depends on the specific conditions of each affected location such as the extent of water hyacinth infestation, regional climate, and proximity to human and wildlife (Villamagna \& Murphy, 2010). Hand removal is most effective for small infestations such as small dams and drains. It is highly laborious and should only be used where the rate of removal can exceed the rate of re-growth. It should be done before flowering and seed set in spring (UNEP, 2012). Mechanical shredding of water hyacinth is cheaper than harvesting (Greenfield, et al., 2006), but there are significant consequences of allowing the plant to die and decompose within the system. Understanding the density threshold at which water hyacinth starts to impact ecosystems, society, and local economies will help management establishment goals for population control that can maximize the social benefits while minimizing the costs of the invasive species (Amy, 2009). Therefore, the best method to control water hyacinth is to prevent it from entering a water body.

Biological control is most effective on larger infestations but it can take several years for it to provide successful control. It involves the use of natural enemies including plant pathogens (Dagno, et al., 2012, Villamagna \& Murphy, 2010). The aim of any biological control is not to eradicate the weed, but to reduce its abundance to a level where it is no longer problematic. While there exists several native enemies of water hyacinth, two South American weevil beetles (Neochetina eichhorniae and Neochetina bruchi) and two water hyacinth moth species (Niphograpta albiguttalis and Xubida infusella) have had effective long-term control of water hyacinth in many countries, notably at Lake Chivero (Zimbabwe), Lake Victoria (Kenya), Louisiana (USA), Mexico, Papua New Guinea and Benin (Williams, et al., 2007; Venter, et al., 2012; Gichuki, et al., 2012; Dagno, et al., 2012). Researchers have identified another tiny insect, Megamelus scutellaris, from South America which is highly hostspecific to water hyacinth and does not pose a threat to native or economically important species (Coetzee, et al., 2009).

\section{Conclusion and Recommendation}

Biological alien invasions are a major driver of biodiversity loss worldwide. Water hyacinth (Eichhornia crassipes) is common and widely distributed all over the world, is challenging the ecological stability of freshwater ecosystems. The spread of invasive alien species is neither easy to manage nor easy to reverse. They are threatening not only biodiversity but also economic development and human wellbeing. Threats are destruction of biodiversity; oxygen depletion and reduced water quality; breeding ground for pests and vectors; blockage of waterways hampering agriculture, fisheries, recreation and hydropower; fishing, grazing and other agricultural activities by forming impenetrable thickets and hindering movements of humans and animals, and destroying and replacing natural biodiversity. Proliferation of water hyacinth is a symptom of broader watershed management and pollution problems.

The best method to control water hyacinth is to prevent it from entering a water body. Development of national and local policies for the detection, control and eradication of invasive species within and around aquatic ecosystems, farm lands, communal lands and in all ecosystems is required to prevent impacts of invasive species ahead not only on biodiversity loss but also, ecosystem and economy of a country. Therefore, the recommendation based on this review is that Ethiopian Government has to declare water hyacinth and other invasive species as a national pest and then put legislation in place to control them. Since Ethiopia being a member of Convention on Biological Diversity (CBD) which urges the parties to "prevent the introduction of, control, or eradicate those alien species which threaten ecosystem, habitat or species"; the impact of invasive weeds on environment, article 8(h) of the CBD signed by 161 countries at the Earth Summit in 1992.

\section{Reference}

- $\quad$ Alimi T. \& Akinyemiju OA., (1991). Effects of water hyacinth on water transportation in Nigeria. Journal of Aquatic Plant Management; 29:109-112.

- $\quad$ Amy MV., (2009). Ecological effects of water hyacinth (Eichhornia crassipes) on Lake Chapala, Mexico. Dissertation submitted to the Faculty of the Virginia Polytechnic Institute and State University, Blacksburg, Virginia.

- $\quad$ Aoi T. \& Hayashi T., (1996). Nutrient removal by water lettuce (Pisitia stratiotes). Water Science and Technology; 34: 407-412.

- $\quad$ Aweke G., (1994). The water hyacinth (Eichhornia crassipes) in Ethiopia. Bulletin des Séances, Académie Royale des Sciences d'Outre-Mer; 39(3):399-404.

- $\quad$ Ayalew W., Ali S., Eyayu M., Goraw G., W/Gebriel G/K., Agegnehu Sh., Dereje T. \& Muluneh G., (2012). Preliminary Assessment of Water hyacinth (Eichornia crassipes) in Lake Tana. Proceedings of National Workshop (Biological Society of Ethiopia), Addis Ababa 
- $\quad$ Batcher MS., (2000). Eichhornia crassipes (Martius) Solms. Element Stewartship Abstract. Arlington, USA: The Nature Conservancy.

- Bureau of Environmental Protection, Administration and Use (BoEPLAU), (2012). In: Wassie A., Minwuyelet M., Ayalew W., Dereje T., Woldegebrael W/K., Addisalem A. \& Wondie E. (2014). Water hyacinth coverage survey report on Lake Tana, Technical Report Series 1

- $\quad$ Center TD., (ed). (1994). Biological Control of weeds: water hyacinth and water lettuce. Intercept, Andover.

- Chapman D., (ed). (1996). Water quality assessments: A guide to the use of biota, sediments and water in environmental modeling. Chapman \& Hall, London.

- $\quad$ Chunkao K., Nimpee C, \& Duangmal, (2012). The King's initiatives using water hyacinth to remove heavy metals and plant nutrients from wastewater through Bueng Makkasan in Bangkok, Thailand. Ecological Engineering; 39: 40-52.

- $\quad$ Coetzee J., Hill M., Julien M., Center T. \& Cordo H., (2009). Eichhornia crassipes (Mart.) Solms-Laub. (Pontederiaceae).

- Dagno K., Lahlali R., Diourte M. \& Haissam J., (2012). Fungi occurring on waterhyacinth (Eichhornia crassipes [Martius] Solms-Laubach) in Niger River in Mali and their evaluation as Mycoherbicides. J. Aquat. Plant Manage; 50: 25-32.

- Dereje T., Erkie A., Wondie Z. \& Brehan M., (2017). Identification of impacts, some biology of water hyacinth (Eichhornia crassipes) and its management options in Lake Tana, Ethiopia. Net Journal of Agricultural Science; 5(1): 8-15.

- $\quad$ Edwards D. \& Musil CJ., (1975). Eichhornia crassipes in South Africa - a general review. J. Limnological Soc. Southern Afr.; 1: 23-27.

- $\quad$ Firehun Y., Struik PC., Lantinga EA. \& Taye T., (2014). Water hyacinth in the rift valley water bodies of Ethiopia its distribution socioeconomic importance and management. IJCAR; 3: 67-75.

- $\quad$ FAO, (2002). Management of problematic aquatic weeds in Africa FAO efforts and achievements during the period 1991-2001, Rome, Italy

- Frezina NCA., (2013). Assessment and utilization of water hyacinth in the water bodies of Tamil Nadu. IJSRP, 2: 58-77.

- $\quad$ Gerry H., Waage J.and Phiri G., (1997). The problem in tropical Africa. Report prepared for the first meeting on and international water hyacinth consortium held at the World Bank, Washington 18-19 March, 1997.

- $\quad$ Gichuki J., Omondi R., Boera P., Tom Okorut T., SaidMatano A., Jembe T. \& Ofulla A., (2012). Water Hyacinth Eichhornia crassipes (Mart.) Solms-Laubach Dynamics and Succession in the Nyanza Gulf of Lake Victoria (East Africa): Implications for Water Quality and Biodiversity Conservation. The Scientific World Journal,

- Gopal P., (1987). Aquatic Plant studies 1: Water hyacinth. Netherlands Elsevier Science Publishers B. V

- Greenfield BK., Blankinship M. \& McNabb TJ., (2006). Control costs, operation, and permitting issues for non-chemical plant control: Case studies in the San Francisco Bay-Delta Region, California. Journal of Aquatic Plant Management; 44: 40-49.

- $\quad$ Harley KLS., Julien MH. \& Wright AD., (1996). Water hyacinth: a tropical worldwide problem and methods for its control. In: Julissa RS. \& Pedro A-R., 2013. Eichhornia crassipes (water hyacinth). Department of Botany-Smithsonian NMNH, Washington DC, USA, /accessed on December 01, $2017 /$.

- $\quad$ Hill G., Cock M. \& Howard G., (1999). A global review of water hyacinth - its control and utilization. CABI Bioscience and IUCN

- $\quad$ Hill MP. \& Coetzee JA., (2008). Integrated control of water hyacinth in Africa. EPPO Bull. 38: $452-457$

- Holm LG., Weldon LG. \& Blackburn RD., (1969). Aquatic weeds. Science; 166:699-709.

- $\quad$ Holm L., Doll J., Holm E., Pancho J. \& Herberger J., (1997). World Weeds. Natural Histories and Distribution. New York, USA: John Wiley and Sons, Inc

- LVEMP, (1995). Lake Victoria Environmental Management programme. Report submitted by Kenya, Uganda and Tanzania to World Bank.

- $\quad$ Kateregga E. \& Sterner T., (2009). Lake Victoria fish stocks and the effects of water hyacinth. The Journal of Environment \& Development; 18: 62-78.

- $\quad$ Maceina M J., Cichra M., Betsill R. \& Bettoli P., (1992). Limnological changes in a large reservoir following vegetation removal by grass carp. Journal of Freshwater Ecology; 7:81-93.

- $\quad$ Mack RN., Simberloff D., Lonsdale WM., Evans H., Clout M. \& Bazzaz FA., (2000). Biotic invasions: Causes, epidemiology, global consequences, and control. Ecological Applications 10: 689-710.

- $\quad$ Manson JG. \& Manson BE., (1958). Water hyacinth reproduces by seed in New Zealand. New Zealand Jour. Agric.; 96: 191.

- Makhanu KS., (1997). Impact of Water hyacinth in Lake Victoria. In: Water and Sanitation for all: Partnerships and Innovations. 23rd Water Engineering and Development Centre Conference Durban, South 
Africa.

- Mangas-Ramirez E. \& Elias-Gutierrez M., (2004). Effect of mechanical removal of water hyacinth (Eichhornia crassipes) on the water quality and biological communities in a Mexican reservoir. Journal of Aquatic Health and Management; 7: 161-168.

- $\quad$ Matthews LJ., Manson BE. \& Coffey BT., (1977). Longevity of water hyacinth (Eichhornia crassipes (Mart.) Solms) seed in New Zealand. Proc. Asian-Pacific Weed Sci. Soc. Conf. 1968; 1: 263-267.

- $\quad$ Meerhoff M., Fosalba C., Bruzzone C., Mazzeo N., Noordoven W. \& Jeppesen E., (2006). An experimental study of habitat choice by Daphnia: plants signal danger more than refuge in subtropical lakes. Freshwater Biology; 51: 1320-1330.

- $\quad$ McVea C. \& Boyd CE., (1975). Effects of water-hyacinth cover on water chemistry, phytoplankton, and fish in Ponds. Journal of Environmental Quality; 4: 375-378.

- Millennium Ecosystem Assessment (2005). Ecosystems and Human Well-being: Biodiversity Synthesis. World Resources Institute, Washington, DC

- Minakawa N., Seda P., Yan G., (2002). Influence of host and larval habitat distribution on the abundance of African malaria vectors in western Kenya. Am J Trop Med Hyg.; 67:32-38. [PubMed]

- $\quad$ Mironga JM., Mathooko J M. \& Onywere SM., (2011). The Effect of Water Hyacinth (Eichhornia Crassipes) Infestation on Phytoplankton Productivity in Lake Naivasha and the Status of Control. Journal of Environmental Science and Engineering; 5(10): 1252-1261

- $\quad$ Mitchell DS., (1985). Surface-floating aquatic macrophytes. pp. 109-124 In: The Ecology and Management of African Wetland Vegetation P. Denny, editor. W. Junk Publishers, Dordrecht.

- $\quad$ Navarro L. \& Phiri G., (2000). Water hyacinth in Africa and the Middle East. A survey of problems and solutions. International Development Research Centre, Ottawa (CA).

- $\quad$ Noboru M.,Gabriel OD.,George OS., Kyoko F., \& Sammy MN., (2012). Malaria Vectors in Lake Victoria and Adjacent Habitats in Western Kenya. PLoS One; 7(3): e32725

- $\quad$ Ndimele P., Kumolu-Johnson C. and Anetekhai M., (2011). The invasive aquatic macrophyte, water hyacinth \{Eichhornia crassipes (Mart.) Solm-Laubach: Pontedericeae\}: problems and prospects. Res J Environ Sci 5:509-520.

- Obeid M., (1984). Water hyacinth, (Eichhorina crassipes Mart.) solms. in Sudan. Proceedings of the international conference on water hyacinth . Hyderabad, India, pp. 145-148.

- $\quad$ Osumo MW., (2001). Effects of water hyacinth on water quality of winam gulf, lake victoria. UNU-Fisheries Training Programme, Skulagata 4120 Reykjavik, Iceland

- $\quad$ Patel S., (2012). Threats, management and envisaged utilizations of aquatic weed Eichhornia crassipes: an overview. Rev Environ Sci Biotechnol; 11:249- 259.

- $\quad$ Rakotoarisoa TF., Waeber PO., Richter T. \& Mantilla Contreras IJ., (2015). Water hyacinth (Eichhornia crassipes) any opportunities for the Alaotra wetlands and livelihoods. $M C D ; 10: 128-136$.

- $\quad$ Rands M., Adams W., Bennun L., Butchart S., Clements A., Coomes D., Entwistle A., Hodge I., Kapos V., Scharlemann J., Sutherland W. \& Vira B., (2010). Biodiversity conservation: Challenges beyond 2010. Science; 329: 1298-1303.

- $\quad$ Richards DI., Small J. \& Osborne J., (1985). Response of zooplankton to the reduction and elimination of submerged vegetation by grass carp and herbicides in four Florida lakes. Hydrobiologia; 123:97-108.

- $\quad$ Roger HH. \& Davis DE., (1972). Nutrient removal by water hyacinth. Weed Sci.; 20: 423-427; In: Dereje T., Erkie A., Wondie Z. \& Brehan M. (2017). Identification of impacts, some biology of water hyacinth (Eichhornia crassipes) and its management options in Lake Tana, Ethiopia. Net Journal of Agricultural Science; 5(1): 8-15.

- $\quad$ Rommens W., Maes J., Dekeza N., Inghelbrecht P., Nhiwatiwa T., Holsters E., Ollevier F., Marshall B. \& Brendonck L., (2003). The impact of water hyacinth (E. crassipes) in a eutrophic subtropical impoundment (Lake Chivero, Zimbabwe). I. Water quality. Archiv Fur Hydrobiologie; 158: 373-388

- $\quad$ Suski CD., \& Cooke SJ., (2007). Conservation of aquatic resources through the use of freshwater protected areas: Opportunities and challenges. Biodiversity and Conservation; 16: 2015-2029.

- Terry PJ., (1996). The water hyacinth problem in Malawi and foreseen methods of control. Strategies for Water Hyacinth Control. Report of a panel of experts meeting, 1995, Fort Lauderdale, USA. Rome, Italy: FAO, 59-81.

- $\quad$ Tiwari S., Dixit S. \& Verma N., (2007). An effective means of biofiltration of heavy metal contaminated water bodies using aquatic weed Eichhornia crassipes. Environmental Monitoring and Assessment; 129: 253256.

- $\quad$ Twongo T. \& Howard G., (1998). Ways with weeds. New Scientist; 159: 57-57

- UNEP, (2012). Fifth Global Environment Outlook (GEO5): Environment for the future we want. United Nations Environment Programme, Nairobi.

- $\quad$ Venter N., Hill M., Hutchinson S. \& Ripley B., (2012). Weevil borne microbes contribute as much to the 
reduction of photosynthesis in water hyacinth as does herbivory. Biological Control; 64: 138-142.

- Villamagna A. \& Murphy B., (2010). Ecological and socio-economic impacts of invasive water hyacinth (Eichhornia crassipes): a review. Freshwater Biology; 55: 282- 298

- $\quad$ Wassie A., Minwuyelet M., Ayalew W., Dereje T., Woldegebrael W/K., Addisalem A. \& Wondie E., (2014). Water hyacinth coverage survey report on Lake Tana, Technical Report Series 1

- Warnimont FJ., (1965). Problem in the Congo. The water hyacinth problem in the Congo catchment area. Democratic Republic of Congo, Leopoldville; 23.

- $\quad$ Williams A., Hecky R. \& Duthie H., (2007). Water hyacinth decline across Lake Victoria-Was it caused by climatic perturbation or biological control? A reply. Aquatic Bot; 87:94-96.

- $\quad$ Wilson JRU., Ajuonu O., Center TD., Hill MP., Julien MH., Katagira FF., Neuenschwander P., Njoka SW., Ogwang J., Reeder RH. \& Van T., (2007). The decline of water hyacinth on Lake Victoria was due to biological control by Neochetina spp. Aquatic Botany; 87: 90-93.

- $\quad$ Wondie Z., (2013). Assessment of water Hyacinth (Eichhornia crassipes (Mart) Solms) in relation to water quality, composition and abundance of plankton and macro- invertebrates in the north-eastern part of Lake Tana, Ethiopia.

- $\quad$ Zimmels Y., Kirzhner F. \& Malkovskaja A., (2007). Advanced extraction and lower bounds for removal of pollutants from wastewater by water plants. Water Environment Research; 79: 287-296. 